\title{
Impact Evaluation of a Decommissioned Landfill on Surrounding Groundwater Quality-a case study, Wang-Tien Landfill Site- southwest Taiwan
}

\author{
Hsien-Jui Yu, Chao-Shi Chen, Chia-Huei Tu, Ying Chia Ni, and Cheng-Wei Wu \\ Department of Resource Engineering, National Cheng Kung University, No.1, University Road, Tainan City 701, Taiwan
}

\begin{abstract}
Landfill leachate composes the potential risk of terrible environmental contamination due to the release of diverse pollutants leaking from the containment system. Hence, a study of contaminant transport is of interest for its suitable management. The aim of this paper was to evaluate groundwater pollution risks from contaminants near the decommissioned Wang-Tien landfill site using a numerical approach. Stable concentrations of various physicalchemical parameters were determined in surface and groundwater samples collected from the study area. Principal component analysis was applied and identified chloride concentrations as the main indicators of groundwater contamination caused by landfill leachate. In this study, Groundwater Modelling System (GMS) was used to predict the subsurface migration of contamination within 1 , and 10 years. The numerical results of chloride have shown that the concentration in the adjacent creek of landfill was $782 \mathrm{mg} / \mathrm{l}$. However, the Monitoring Standard Value of Environmental Protection Administration (EPA, in Taiwan) for Taiwan defined the maximum value of chloride in groundwater for $625 \mathrm{mg} / \mathrm{l}$. The result shows that chloride migrated widely to other places, such as the creek, and has had an adverse effect on the environment.
\end{abstract}

\section{Introduction}

Landfills were generally not capped after closure to avoid the formation of leachate due to the infiltration of rainwater, nor were precautions taken to prohibit the spreading of leachate to underlying aquifers. Therefore, landfills need to be managed and controlled to avoid negative impacts on the environment after closure. Chloride is recognized as a pollutant that has lasting adverse on an ecosystem. High levels of chloride discharged into freshwater bodies may be harmful to fish and other aquatic organisms which are not adapted to live in saline environments. At the present time, GMS is widely used to model and simulate saturated groundwater flow. Many studies use the GMS software package and its features to predict and simulate conditions and conductivity of groundwater and the contamination of groundwater [1-6].

In this paper, a numerical modelling package, GMS (version 7.1.), was used to predict the fate and transport of chlorides in a decommissioned landfill located in Yong-Kang, Tainan City, Taiwan. Generally, as a first step in any predictive analysis, it is necessary to generate the observed conditions in model calibration. The process of calibrating flow and transport models typically involves several steps. The modelling of groundwater flow and contaminant transport at the Wang-Tien landfill site was begun before the field investigations had been completed; this allowed the model requirements to drive portions of the numerical model.

\section{Materials and Methods}

The procedure for applying a groundwater model includes the following steps: define study objectives, develop a conceptual model, construct a groundwater flow model, calibrate the groundwater flow model and perform sensitivity analysis, set a contaminant transport model, calibrate the model, make predictive simulations, document the modeling process, and perform a post audit. A modelling process is shown in Figure 1.

\subsection{Description of study site}

The study site, the Wang-Tien landfill, is located in the Yong-Kang Municipality of the Tainan region. The location of the study area lies between the following coordinates: $120^{\circ} 16^{\prime} 1$ ' E, $120^{\circ} 16^{\prime} 22^{\prime \prime} \mathrm{E}$ longitude and $23^{\circ} 2^{\prime} 29^{\prime \prime} \mathrm{N}, 23^{\circ} 22^{\prime} 36^{\prime \prime} \mathrm{N}$ latitude, and it occupies a total area of $0.75 \mathrm{~km}^{2}$. Figure 2 shows the location of the study area in the southwest of Taiwan. The elevation of the study area ranges from 25 to $28 \mathrm{~m}$ above mean sea level, with a mean land surface slope of $0.1 \%$ from southeast to northwest. The length of the landfill site measures $175 \mathrm{~m}$ from south to north, and $225 \mathrm{~m}$ from east to west, and is currently surrounded by an industrial zone. 
Four of hydrogeological bores logs can be seen in Figure 3 , showing the major geological layers in the vicinity of the closed landfill. The site is situated within the HsuHsian creek watershed, which drains into the Yan-Shuei creek. From a regional water balance using historical meteorological data, the regional groundwater recharge rate was estimated to be within a range 0.14 to 0.75 $\mathrm{cm} / \mathrm{min}$. The landfill has been accepting municipal solid waste from the Tainan city since 1992. It was closed in 2002. The accumulative amount of solid waste reached approximately $773,970 \mathrm{~m}^{3}$. The study area is located in a tropical climate zone with an annual average rainfall of $1828.4 \mathrm{~mm}$ and an annual average evaporation of 1476 $\mathrm{mm}$.

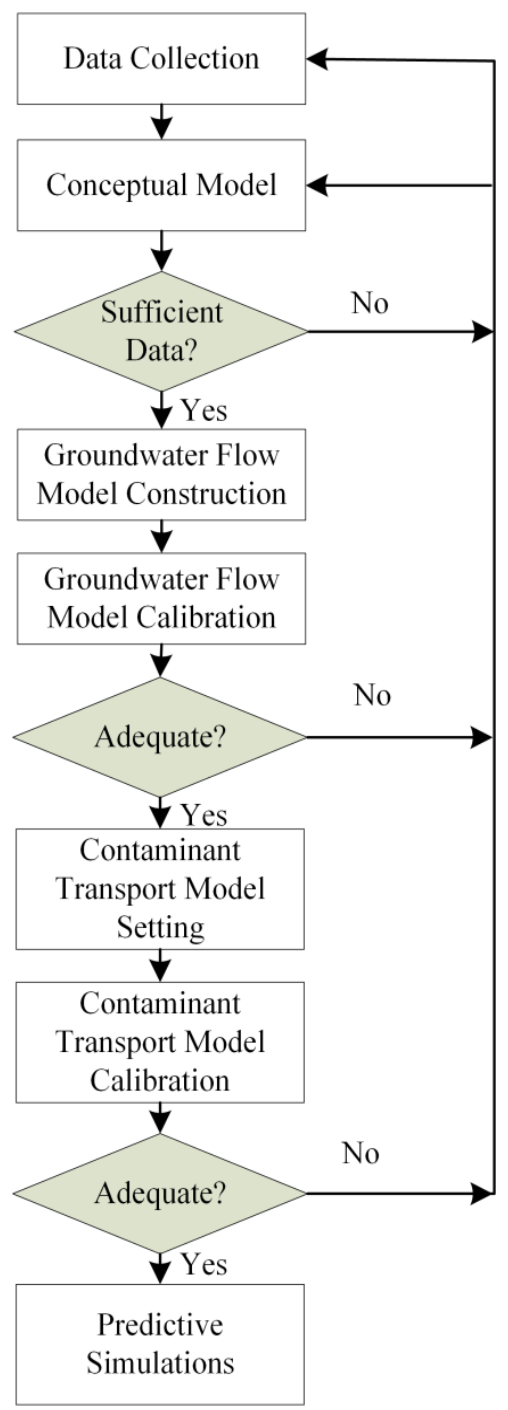

Figure 1. Flowchart of the modelling process

\subsection{Groundwater Data}

Certain parameters assigned in the numerical software for the simulation, including hydraulic conductivity, porosity, thickness and type of soil, were collected between 2013 and 2014 in the study area. Monitoring wells that were purged before sampling and groundwater that was collected by pumping, only after constant values of electrical conductivity and redox potential have been established.

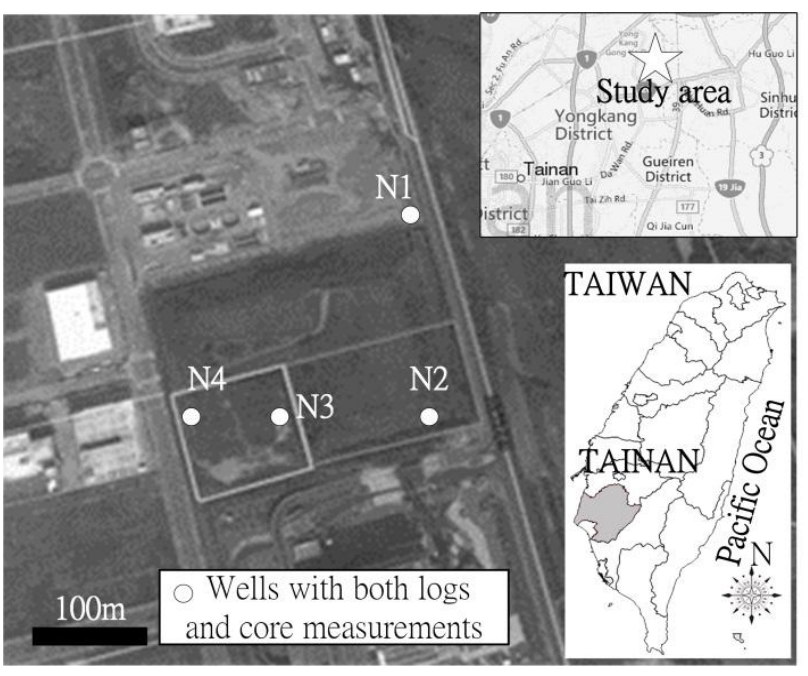

Figure 2. Location of study area.

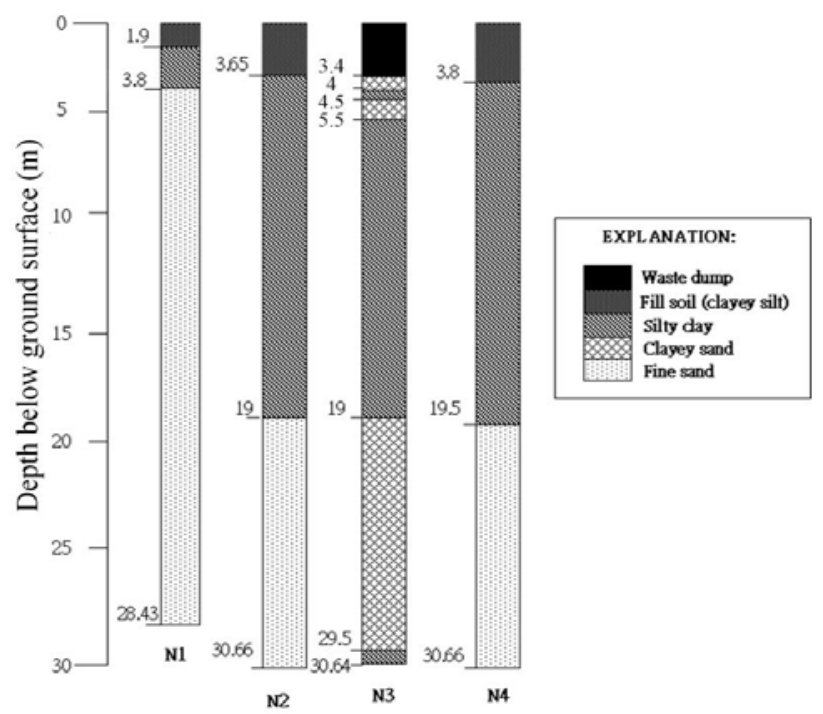

Figure 3. The major geological layers.

The measured physicochemical values of water samples from the study area can be seen in Table 1 . The hydraulic conductivities for the sand layer were obtained from slug testing [7] in boreholes and the measured values of the aquifer from the study site. The hydraulic conductivity tensor in the numerical model was assumed to be isotropic.

\subsection{Groundwater Flow Simulation Model}

MODFLOW solves for the distribution of hydraulic head within the model domain, the velocity components of flow are calculated [8]. The key partial differential equation, as shown in Equation 1, used to predict flow is:

$\frac{\partial}{\partial x}\left(K_{x x} \frac{\partial h}{\partial x}\right)+\frac{\partial}{\partial y}\left(K_{y y} \frac{\partial h}{\partial y}\right)-W=S_{S} \frac{\partial h}{\partial t}$

Where $K_{x x}$, and $K_{y y}$ are the values of hydraulic conductivity along the $x$, and $y$ coordinate axes; $h$ is the potentiometric head; $W$ is a volumetric flux per unit volume representing sources and sinks of water; $S_{S}$ is the specific storage of the material; and $t$ is time 
Table 1. Physico-chemical parameters of water samples around the landfill in 2013.

\begin{tabular}{|c|c|c|c|c|c|}
\hline \multirow[t]{2}{*}{ Indicator of Water Quality } & \multirow[t]{2}{*}{ Unit } & \multicolumn{4}{|c|}{ Level of Pollutants in Wells } \\
\hline & & N1 & N2 & N3 & N4 \\
\hline Temperature & ${ }^{\circ} \mathrm{C}$ & 25.5 & 25.1 & 26.4 & 25.2 \\
\hline $\mathrm{pH}$ & & 7.7 & 7.8 & 7.8 & 7.6 \\
\hline Electrical Conductivity & $\mu \mathrm{S} / \mathrm{cm}$ & 3990 & 2880 & 3110 & 5500 \\
\hline Total Dissolved Matters & $\mathrm{mg} / \mathrm{l}$ & 2100 & 1650 & 1600 & 2850 \\
\hline Total Hardness & $\mathrm{mg} \mathrm{CaCO} / 1$ & 197 & 174 & 114 & 276 \\
\hline Ammonium Nitrogen & $\mathrm{mg} / 1$ & 4.31 & 5.43 & 2.32 & 0.15 \\
\hline Nitrite Nitrogen & $\mathrm{mg} / \mathrm{l}$ & ND & ND & ND & ND \\
\hline Nitrate Nitrogen & $\mathrm{mg} / \mathrm{l}$ & 0.14 & 0.10 & 0.01 & ND \\
\hline total Organic Carbon & $\mathrm{mgC} / 1$ & 3.1 & 13.0 & 1.9 & 2.6 \\
\hline Chlorides & $\mathrm{mg} / \mathrm{l}$ & 899 & 456 & 669 & 1440 \\
\hline Sulphates & $\mathrm{mg} / \mathrm{l}$ & 28.9 & 49.2 & 6.64 & 12.6 \\
\hline Arsenic & $\mathrm{mg} / \mathrm{l}$ & 0.0548 & 0.0699 & 0.0376 & 0.0336 \\
\hline Total Chromium & $\mathrm{mg} / \mathrm{l}$ & ND & ND & ND & ND \\
\hline Copper & $\mathrm{mg} / \mathrm{l}$ & ND & $<0.05$ & ND & ND \\
\hline Manganese & $\mathrm{mg} / \mathrm{l}$ & 0.08 & 0.04 & 0.05 & 0.08 \\
\hline Ferrum Iron & $\mathrm{mg} / \mathrm{l}$ & $<0.05$ & 0.14 & 0.06 & 0.06 \\
\hline Lead & $\mathrm{mg} / \mathrm{l}$ & ND & ND & ND & $<0.10$ \\
\hline Zinc & $\mathrm{mg} / \mathrm{l}$ & $<0.01$ & 0.13 & $<0.01$ & $<0.01$ \\
\hline Nickel & $\mathrm{mg} / \mathrm{l}$ & ND & ND & ND & ND \\
\hline Cadmium & $\mathrm{mg} / \mathrm{l}$ & ND & ND & ND & ND \\
\hline Mercury & $\mathrm{mg} / \mathrm{l}$ & ND & ND & ND & ND \\
\hline Average Hydraulic Conductivities & $\mathrm{m} / \mathrm{min}$ & $7.548 \times 10^{-3}$ & $4.304 \times 10^{-3}$ & $1.855 \times 10^{-3}$ & $1.441 \times 10^{-3}$ \\
\hline
\end{tabular}

\subsection{Contaminant transport model}

To simulate the leaching of chlorides into groundwater, MT3DS was used. MT3DS is a modular threedimensional transport model for the simulation of advection, dispersion, and the chemical reactions of dissolved constituents in groundwater systems. It uses cell-by-cell data, which is calculated and outputted by MODFLOW to establish the results [9]. The advection dispersion equation is written as follows:

$$
\frac{\partial C}{\partial t}=\frac{\partial}{\partial X_{i}}\left[D_{i j} \frac{\partial C}{\partial X_{j}}\right]-\frac{\partial}{\partial X_{i}}\left[v_{i} C\right]+\frac{q_{S}}{\theta} C_{S}+\sum_{K=1}^{N} R_{K}
$$

Where $C$ is dissolved concentration; $\mathrm{t}$ is time; $D_{i j}$ is dispersion coefficient; $\mathrm{v}_{\mathrm{i}}$ is velocity component in $i j$ direction.

\subsection{Model boundaries}

The boundaries assigned in numerical software contain: (i) Constant Head Boundary (CHB), (ii) evapotranspiration boundary, (iii) recharge boundary, and (iv) creek boundary. The assigned values recharge and evapotranspiration to the entire cells of mesh are 1828.4 $\mathrm{mm} / \mathrm{yr}$ and $1195.8 \mathrm{~mm} / \mathrm{yr}$, respectively. Figure 4(a) shows the creek boundary, which is assigned in numerical mesh. The A-A' cross section was chosen to construct the contaminant vertical transport model (Figure 4(b)). The cross section was vertically discretized 10 layers in total with thickness of $2-3 \mathrm{~m}$. the bottom boundary of the model is restricted by depth of available investigation boreholes in this site and is assumed no flow. The flux flowing in or out in the lateral boundaries of the sand aquifer were estimated according the geometry of the boundary and the regional hydraulic gradient.

\subsection{Model calibration}

Model results were used during the calibration phase in order to verify between the simulated results and those observed in the groundwater monitoring wells. The water level measurements taken at the landfill site give the best overall contour of water levels throughout the aquifer.

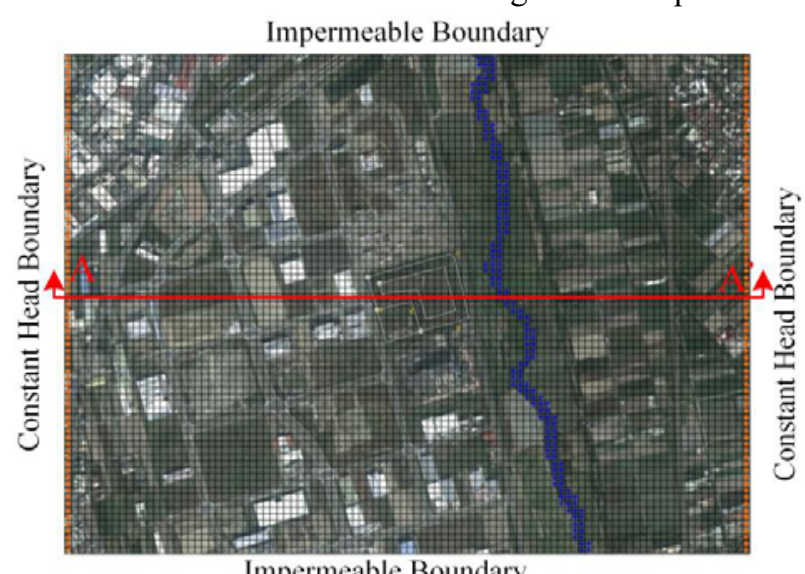

(a) The top view

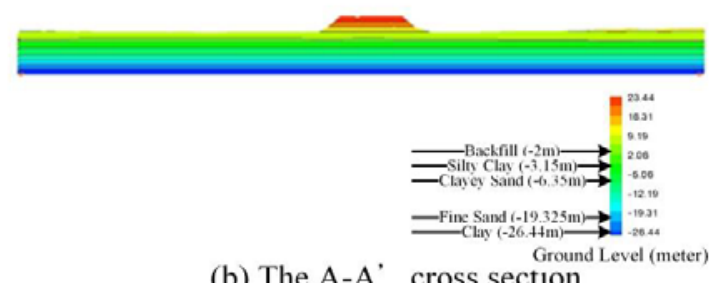

(b) The A-A' cross section

Figure 4. Location of creek boundary in study area 
The initial calibration study used assumed that there was a leachate mound within the landfill. This was based on groundwater level data from N1 to N4 obtained in 2013, as shown in Figure 5(a). Subsequently improved calibrations were applied and assumed that there was no leachate mound. They further assumed that the elevated water level at $\mathrm{N} 1$ to $\mathrm{N} 4$ was the result of perching mainly caused by the recirculation of leachate. A plot of the correlation between calculated and observed hydraulic heads indicates that the flow model calibration is representative of the physical conditions at the landfill site, as shown in Figure 5. To achieve the hydraulic head distribution in the landfill site, the finite difference mesh was set to a cell size of $20 \times 20 \mathrm{~m}$. The results of the calibration are shown in Figure 6, and it can be seen that, generally, good agreement between calculated and observed groundwater levels was achieved.

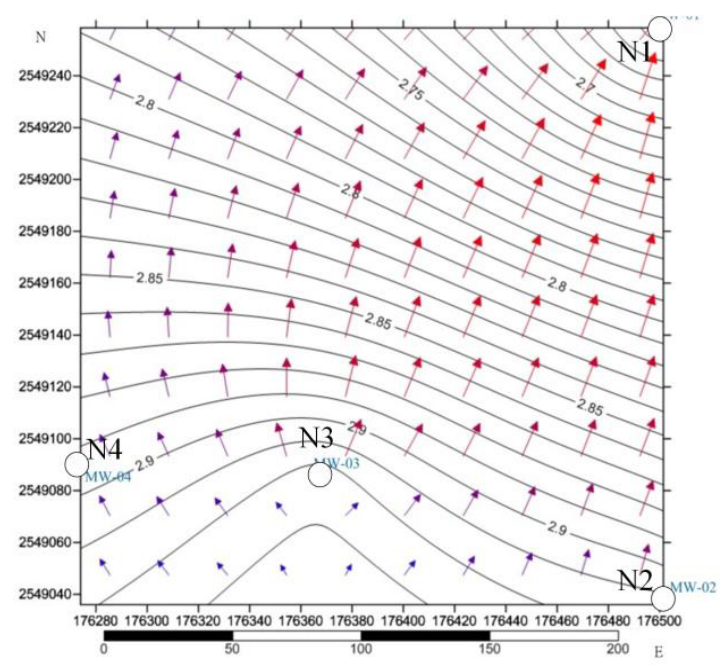

(a) Average groundwater hydraulic head distribution and flow vector in 2013

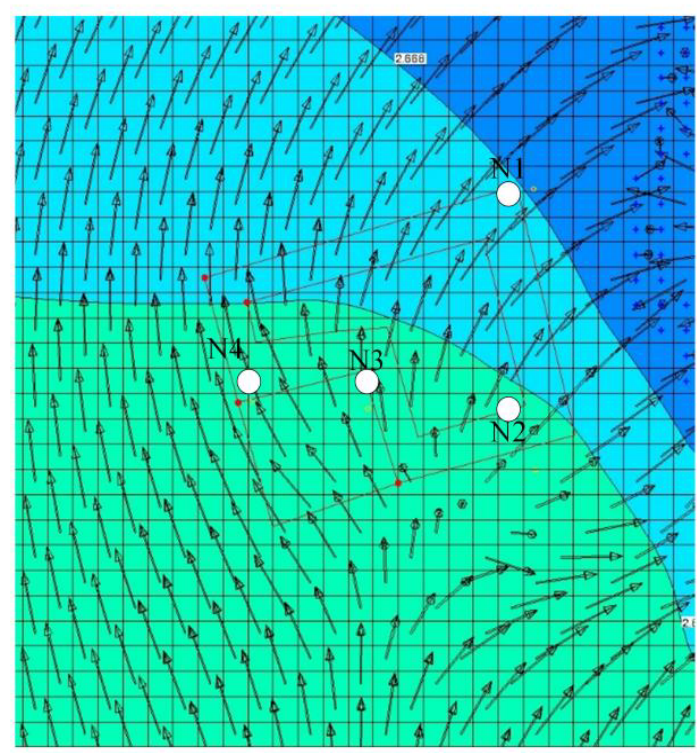

(b) The MODFLOW simulation

Figure 5. Groundwater flow model calibration.

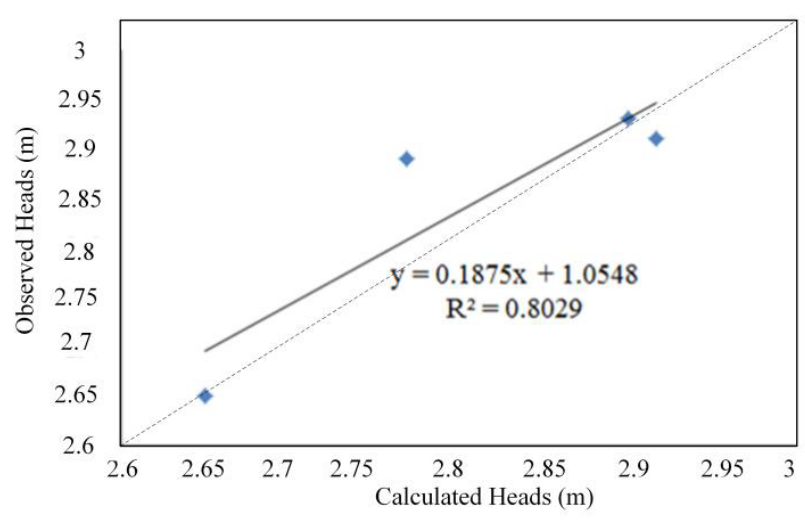

Figure 6. Correlation of calculated vs. observed heads.

In order to investigate the extent of migration of landfill leachate into the sand aquifer and to determine the role of the clay/silt layers, a chloride transport model was constructed. Although groundwater flow in the aquifer is essentially horizontal from the study area, the zone of leachate contamination beneath the landfill has penetrated downward through the entire sand aquifer thickness to a depth of 3.8-30.66 m. Chloride was selected as the conservative tracers because it is generally not likely to undergo any physico-chemical reactions (e.g., adsorption, precipitation, and biological degradation) in the aquifers, and usually it is characterized by high concentrations in leachate-contaminated groundwater near the landfill. Therefore, chloride can be used to study the dispersion and dilution of a contaminant plume. The landfill zone is the main pollution source for groundwater contamination in the study area. A plot of the correlation between concentration calculated and observed indicates that the Contaminant transport model calibration is representative of the physical conditions at the landfill site, as shown in Figure 7.

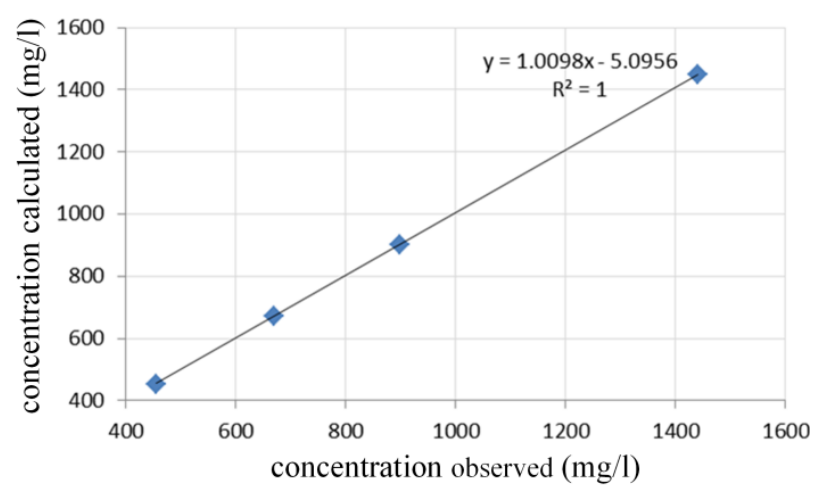

Figure 7. Correlation of calculated vs. observed concentration.

\section{Numerical results}

Results of chloride measurement in the study area show that a concentration of chloride in most parts is low, yet in the adjacent Hsu-Hsian creek of the Wang-Tien landfill concentration of chloride is $782 \mathrm{mg} / \mathrm{l}$. The authors used the MODFLOW and the MT3DMS model that was run to steady-state for 1 and 10 years. As a matter of fact, chloride cannot leach and move with groundwater in the 
short time because of the high absorption capacity soil has for the absorption of chloride particles, but the ability to move chloride is resumed as the adsorption capacity of the soil is reached. This enables the groundwater carried chloride to go around the soil particles, which in turn allows for the transportation of high concentrations of chloride through the soil. The results illustrate that chloride did not migrate widely along the groundwater flow (Figure 8). But after 10 years, the contamination plume is moving in the direction of the northeast (into the creek which is located in east of map) instead of moving along with groundwater. As shown in Figure 8, the contamination plume is moving toward the creek and is seeping into surface water and is transported to other places.

Due to the placement of the decommissioned landfill (which is located at a higher ground level and the creek is beside the landfill, which is located at a lower ground level), movement of the groundwater in the study area is effective by the Hsu-Hsian creek that is located in east of the study area, and the movement of the contamination in the direction of the northeast (into the creek) is shown in Figure 9.

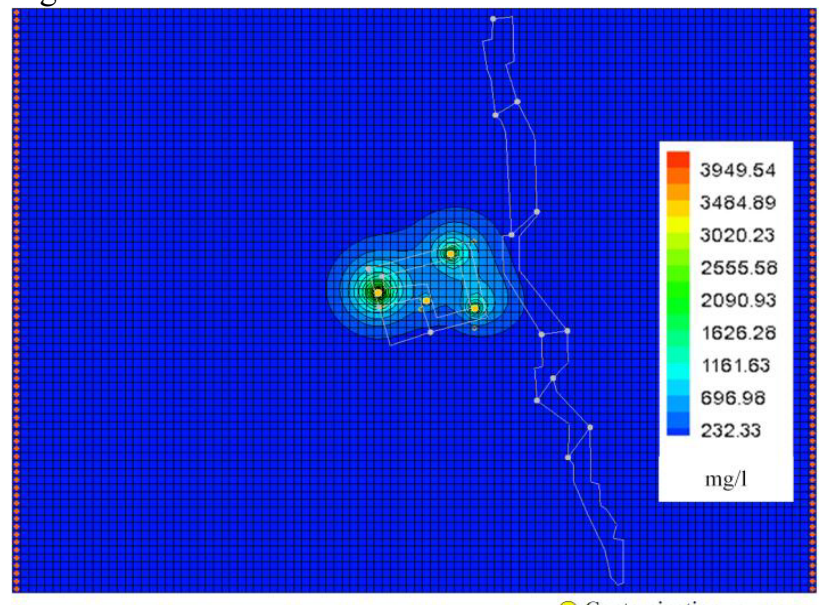

Contamination source

Figure 8. Migration of contamination after 1 year

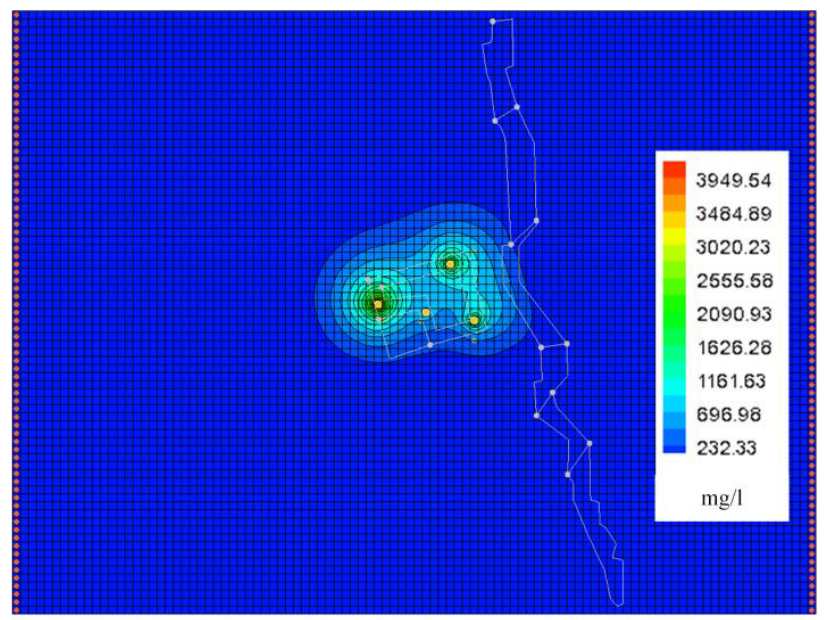

Contamination source

Figure 9. Migration of contamination after 10 year

\section{Conclusion}

An advective-dispersive transport model was established using MODFLOW and MT3DMS to simulate the chloride plume in the upper sand unit. A steady state was simulated and discussed. Chloride transport simulation shows that after 10 years operation of the closed landfill, the contamination plume is still constrained to the upper aquifer. The seasonal dynamics of the hydraulic condition, such as recharge and water level temporal variations, should be investigated further to evaluate the migration of the plume under the landfill. Groundwater flow and concentration transport modelling was valid for assessing and predicting chloride concentrations in the subsurface zone in the landfill zone. The prediction of chloride migration in groundwater might be a preliminary research, and further study must be implemented to investigate the migration of chloride better to prevent the spreading of chloride in study area. The present research confirms that the unconfined aquifer is highly contaminated by chloride, which is $782 \mathrm{mg} / \mathrm{l}$ when standard of the Monitoring Standard Value for Taiwan is declared by Environmental Protection Administration (EPA) $675 \mathrm{mg} / \mathrm{l}[10]$. Generally, groundwater around the closed landfill is not suitable for drinking water, and some remedial measures should be considered to improve the groundwater quality around the closed landfill, particularly given the high levels of ecological and agricultural groundwater demand in this area.

\section{Acknowledgment}

This work was supported by the Ministry of Science and Technology of Taiwan (104-2221-E-006-268-) and the Environmental Protection Bureau of Tainan City.

\section{References}

1. Y. Abu-Rukah, O. Al-Kofahi. J. Arid. ENVIRON 49, 615 (2001)

2. A.F. Al-Yaqout, M.F. Hamoda. ENVIRON INT. 29 , 593 (2003)

3. I.S. Babiker, A.A.M. Mohamed, H. Terao, K. Kato, K. Ohta. ENVIRON INT. 29, 1009 (2004)

4. T.H. Christensen, P. Kjeldsen, P.L. Bjerg, D.L. Jensen, J.B. Christensen, A. Baun, H.J. Albrechtsen, G. Heron. Appl. Geochem. 16, 659 (2001)

5. D. Rapti-Caputo, C. Vaccaro. Eng. Geol. 85, 111 (2006)

6. K. Kim, K.S. Ko, Y. Kim, K.S. Lee. CHEMOSPHERE 87, 851 (2012)

7. H. Bouwer, R.C. Rice. WATER RESOUR RES 12, 423 (1976)

8. A.W. Harbaugh, US Geol. Surv. (Tech. Methods 2005)

9. C. Zheng,. Department of Geological Sciences, University of Alabama, (2006) http://hydro.geo.ua.edu/mt3d/.

10. EPA. Regulations for Groundwater Monitoring. Environmental Protection Administration, R.O.C., Taiwan.http://wq.epa.gov.tw/Code/Business/Statutor y.aspx Tabs $=3 \&$ Languages $=$ en $\quad($ accessed on 10 October 2014) 